\title{
Emerging LNG-fueled ships in the Chinese shipping industry: a hybrid analysis on its prospects
}

\author{
Chengpeng Wan • Xinping Yan • Di Zhang • \\ Jing Shi • Shanshan Fu • Adolf K. Y. Ng
}

Received: 1 September 2014 / Accepted: 6 February 2015 /Published online: 17 March 2015

(C) World Maritime University 2015

\begin{abstract}
With the prosperity of global shipping industry, a variety of shippinginduced environmental problems and increasingly rigid emission restrictions have drawn more attention to an emerging marine fuel-liquefied natural gas (LNG), a clean and efficient energy that conforms to the essence of green shipping. Although with superiority using onboard, there are only fewer than 40 fully LNG-fueled ships in service worldwide by June 2013, and the quantity of LNG-fueled ships in operation is even much lower in China. Moreover, the majority of those in China are inland ships, which mainly navigate along the Yangtze River and canals. By using the SWOT (strengths, weaknesses, opportunities, and threats) analysis in combination with the analytic hierarchy process (AHP), this paper analyzes the development prospect of LNG-fueled ships in inland waterway transportation in China, aiming to fill the gaps of inadequate understanding of the new marine energy. This paper offers some insight on the prospects of the application of LNG in the Chinese shipping industry and simultaneously provides useful information to stakeholders and policy makers for decisionmaking on the development of LNG-fueled ships.
\end{abstract}

\section{Wan}

School of Energy \& Power Engineering, Wuhan University of Technology,

Wuhan, People's Republic of China

C. Wan $\cdot$ X. Yan $\cdot$ D. Zhang $(\bowtie) \cdot$ S. Fu

National Engineering Research Center for Water Transport Safety (WTSC),

Wuhan, People's Republic of China

e-mail: zhangdi@whut.edu.cn

C. Wan $\cdot$ X. Yan $\cdot$ D. Zhang $\cdot$ S. Fu

Intelligent Transport Systems Research Center, Wuhan University of Technology, NO. 125, 1040 Heping Avenue, Wuchang Area, Wuhan 430063, China

\section{J. Shi}

Marketing and Operations, Management School, University of Liverpool,

Chatham Building (FE10), Chatham Street, Liverpool L69 7ZH, UK

\section{A. K. Y. Ng}

Department of Supply Chain Management, I.H. Asper School of Business, University of Manitoba, 181 Freedman Crescent, Winnipeg, Manitoba R3T 5V4, Canada 
Keywords Green shipping - LNG-fueled ship - AHP-SWOT - Chinese shipping industry

\section{Introduction}

According to the International Chamber of Shipping (ICS), about $90 \%$ of world trade volume is carried by ships (ICS 2013a). Indeed, shipping has been considered as a very important pillar of economic development since the eighteenth century (Cheng et al. 2013). Apart from the decline in international trade due to the economic downturn which took place in 2008, world seaborne trade has shown a trend of steady growth in the past decade (Fig. 1). The significant role that shipping plays in the Chinese economy is even more obvious, covering about $93 \%$ of China's international trade, $95 \%$ of crude oil trade, and $99 \%$ of iron ore trade.

The prosperity of the shipping industry has been inducing a high demand for maritime bunker fuel while at the same time accelerating the deterioration of our environment. According to the International Maritime Organization (IMO), in 2007, international shipping was responsible for approximately 870 million tons of $\mathrm{CO}_{2}$ emission (around $2.7 \%$ of the global emission) (IMO 2009) and the amount is expected to grow as a result of the shipping industry development if no further emission control measures are going to take place. Therefore, the mitigation of environmental impact and reduction of energy consumption are urgently required, while gaining the benefits from shipping industry. Green shipping has emerged showing higher priority to energy efficiency improvement of ships via advanced vessel design and management, rather than simply increasing the scale of ship fleets.

Although there is no general definition for green shipping, its core idea is to achieve the goal of sustainable economy development by keeping a balance between productivity gain and environmental protection (Cheng et al. 2013). This has been well acknowledged among shipping companies and policy makers alike. On July 10, 2012, the China Classification Society (CCS) has promulgated a specification focusing on the energy efficiency, environmental protection, and working environment of ships, namely Rules for Green Ships, which was published on October 1, 2012. It aims to "Achieve the goals of low consumption, low emissions, low pollution and comfortable working environment for ships" (CSC 2012). Among the clean energy utilization technologies, an important topic that has been attracting attention these years is the study of liquefied natural gas (LNG) as a marine fuel.

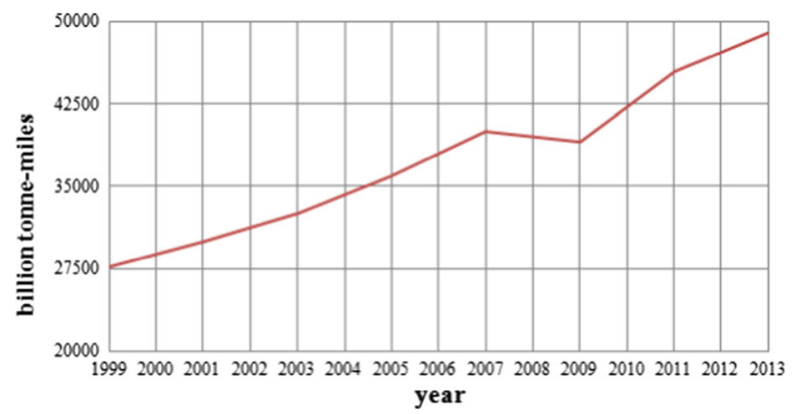

Fig. 1 World seaborne trade (ICS 2013b). Source: International Chamber of Shipping (2013) 


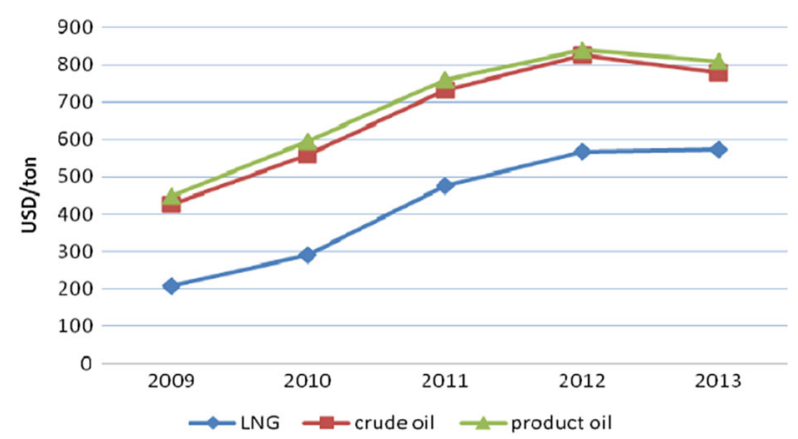

Fig. 2 Trend of weighted average import price of LNG, crude oil, and product oil in China (CNII 2014)

LNG has a series of superiorities including odorless, non-toxic, and non-corrosive (Kumar et al. 2011). The relative low prices of LNG may also make it competitive to some extents to be an alternative for marine fuel. The comparison of weighted average import price of LNG, crude oil, and product oil in China can be seen in Fig. 2.

However, the calorific value of mixing gas composed of LNG and air is about $10.5 \%$ lower than the composition of diesel and air, leading to a certain power coastdown of transformed dual fuel engines (Dong 2011). Taking the calorific value as an index for comparison of power performance, the low calorific value of LNG is $33.75 \mathrm{MJ} / \mathrm{m}^{3}$ while that of $0 \#$ diesel oil is $38.44 \mathrm{MJ} / \mathrm{L}$, so the amount of LNG needed to achieve the same power performance as $1 \mathrm{~L} 0 \#$ diesel oil does is about $1.14 \mathrm{~m}^{3}$, which will be more if combustion efficiency is counted. This can be one of the main reasons to blunt the price advantages of LNG. Beyond that, the fluctuant price (differential) is easily affected by various external factors, which make it difficult to be assessed. Thus, LNG's major advantages lie in environmental protection and the improvement of working environment rather than energy efficiency in the view of green shipping. Moreover, due to inherent property (virtually no sulfur content) and superior combustion performance that reduces the generation of nitrogen oxides $\left(\mathrm{NO}_{x}\right)$ by $85-90 \%$ and carbon dioxide $\left(\mathrm{CO}_{2}\right)$ by 20-25\% compared with heavy fuel oil (Heir et al. 2011), LNG enables ships to meet the International Convention for the Prevention of Pollution from Ships (MARPOL) Annex VI's requirements for both worldwide trade and operation in the Emission Control Areas ${ }^{1}$ (ECAs) without further post treatment. LNG's superiority as a preferable alternative to traditional marine fuels has been further illustrated in researches (Nikopoulou et al. 2013; Acciaro 2014), with emphasis toward lessening environmental impact, compliance with more stringent regulations, or financial concerns. Although LNG was first put in use on LNG carriers in the 1960s (Burel et al. 2013), it has not been applied to other types of ships as a main propulsion fuel until 2000, and this delay is even more explicit in China. The existing reviews on the application of LNG in Chinese transportation industry are mainly about generic LNGpowered vehicles (e.g., Ma et al. 2013) or some specific parts of LNG industry, like

\footnotetext{
${ }^{1}$ Emission Control Areas (ECAs) are sea areas in which stricter controls were established to minimize airborne emissions like $\mathrm{SO}_{x}$ and $\mathrm{NO}_{x}$ from ships. As of 2011, there were four existing ECAs including the Baltic Sea, the North Sea and the North American ECA (most of US and Canadian coast and the US Caribbean ECA included).
} 
LNG plants and receiving terminals (e.g., Shi et al. 2010; Lin et al. 2010). There is a scarcity of studies on the development of LNG as a marine fuel, especially in China.

Therefore, the aim of this article is to investigate (1) what is the current development of LNG-fueled ships in China and (2) how to evaluate its prospects. For these purposes, a quantitative analysis on the development prospect of LNG-fueled ships in inland waterways of China is conducted using a hybrid method of SWOT (strengths, weaknesses, opportunities, and threats) and AHP (analytic hierarchy process). The key factors that influence the development of LNG in Chinese shipping industry are identified in order to provide useful information on this emerging marine fuel for the stakeholders and policy makers. This work would contribute to the research on LNG as a fuel for ships and provide significant reference on the evaluation of its development prospect.

The rest of this paper is organized as follows. Section 2 introduces the current development of LNG-fueled ships in China as well as experimental results of China's first diesel-LNG dual-fueled ship in inland waterways. Section 3 develops a hybrid method with combination of AHP and SWOT framework in order to achieve practicability of prospect analysis. The advantages of the newly reformed approach are analyzed and discussed in this section. By using the AHP-SWOT method, section 4 analyzes the development perspective of LNG-fueled ships in Chinese shipping industry followed by a discussion of validity of calculation results. Finally, the paper is concluded in section 5 .

\section{Overview of LNG-fueled ships in China}

In recent years, the import volume of LNG in China showed a continuously increasing trend which reached 18 million tons in 2013 (shown as Fig. 3), accounting for $47 \%$ of the world total LNG import volume. China's strong demand for LNG has facilitated the LNG trade worldwide, as well as its application in the transportation industry, especially for shipping.

Despite the Chinese shipping industry, as a whole, being in its embryonic stages with regard to LNG, policy makers, stakeholders, and oil companies have shown great interests in using LNG as a marine fuel. For example, the Chinese maritime authorities, together with shipping companies, have carried out relevant studies on LNG-fueled ships in inland waterways, and some progress has been made on the design of LNG storage tanks, specialized LNG-refueling ships, and natural gas engines. According to a

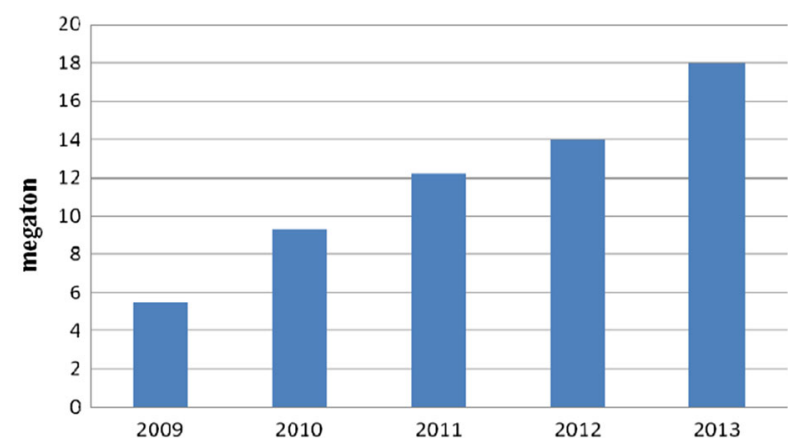

Fig. 3 Import volume of LNG in China from 2009 to 2013. Source: Qianzhan database (2014) 
recent study of China Waterborne Transport Research Institute (Gao 2014), there are about 30,000 ships in inland waterways that meet the requirements for dual-fuel engine conversion, with less than 7 years of usage and in good technical conditions. It is also predicted that a market for LNG-fueled ship conversion will be worth at least 4.96 billion USD in the coming decade (Hu 2013). Thus, LNG-fueled ships have accelerated development within China under the impetus of relevant policies and research; albeit with a later start than developed countries like Norway and Japan. However, there are some existing barriers in efforts to implement LNG in the Chinese shipping industry, such as the difficulty in the layout of LNG storage tanks on ship caused by increasing volume and system complexity, high conversion cost, poor infrastructure for refueling, lack of standards of relevant industrial product, and a lag in natural gas exploitation techniques (Xia 2013).

At present, marine diesel oil (MDO) is the commonly used one for generating forward motion used on inland and coastal ships under 5000 dead weight tonnages (DWT) in China, while the fuel for 5000 DWT ships and above is either the marine fuel oil (MFO) or MDO. When compared to MFO, LNG's advantages are reflected through the benefit to environment by reduction of pollutant emission like $\mathrm{CO}_{2}$ and $\mathrm{NO}_{x}$, rather than economic concerns. However, most refitted trial ships in operation in China are powered by diesel-LNG dual-fuel engines, which only use diesel during berthing and departing. A case study (Zhou et al. 2013) indicated that a cargo ship with 3000 DWT voyaging between Wuhan and Shanghai could save about 72,000 USD on fuel expense per year after being converted to a diesel-LNG dual-fuel engine (at a conversion costs of more than 80,000 USD and part of ships' conversion costs are shown as Table 1), with an average LNG substitution rate of $70 \%$. This means that the cost recovery cycle of ship reconstruction would be around 13 months. On August 3, 2010, China's first diesel-LNG dual-fueled ship in inland waterways reconstructed from a ferry named Wuhan Ferry NO. 302 successfully carried out a 25-day trial in the Yangtze River. The trial data from this breakthrough ship showed a significant reduction on engine noise and pollutant emission under the rated voyaging conditions (Wang 2011b). By the end of June 2013, 121 ships (115 inland ships and 6 seagoing ships) had been approved by China Maritime Safety Administration (MSA) to conduct ship conversion; 107 of which are currently undergoing major modifications. Moreover, according to a document (Ministry of Transport of China 2014) published on October 21, 2014, there will be another 979 newly built LNG-fueled ships and more than ten LNG-filling stations by the end of 2016. The main ship types include bulk cargo ships, container ships, and port tugs.

Table 1 Conversion costs of part of LNG-fueled ships

\begin{tabular}{llll}
\hline Vessel name & Vessel type & Gross tonnage (ton) & Conversion costs (USD) \\
\hline Changxun NO. 3 & Bulk cargo ship & 2590 & 193,000 \\
Hongri NO. 166 & Dry cargo ship & 1808 & 85,000 \\
Changneng NO. 12 & Dry cargo ship & 3718 & 89,000 \\
Jiangsu cargo NO. 3001 & Bulk cargo ship & 2000 & 66,000 \\
Fuzhou NO. 0608 & Dry cargo ship & 831 & 61,000 \\
\hline
\end{tabular}


In particular, LNG-fueled ships discussed in this paper refer to those using LNG as bunker fuel (either refitted ships or new construction) rather than LNG carriers.

\section{Methodology}

\subsection{SWOT analysis}

With the understanding that there are many approaches and techniques in strategic science, the SWOT analysis (strengths, weaknesses, opportunities, and threats) is one of the most popular (Kajanus et al. 2004) and provides a systematic analysis toward case studies (Halla 2007). SWOT has been extensively used in strategic decision-making and competitive analysis in many fields, such as market research, business management, and competitor analysis (Wang 2011a; Luo and Jin 2014). However, traditional application of SWOT analysis cannot evaluate the situation comprehensively (Hill and Westbrook 1997; Tahernejad et al. 2013). In addition, it lacks any quantitative measurement on the degree of importance for each factor and, thus, not possible to determine the level of influence from each factor (Jiang et al. 2012). Therefore, the result of SWOT analysis is sometimes an imprecise list or an incomplete qualitative examination of internal and external factors (Kurttila et al. 2000).

\subsection{Application of AHP in SWOT analysis}

In view of the above SWOT deficiencies, this paper intertwines the analytical hierarchy process (AHP) to solve those complex decision problems with multiple criteria (Saaty 1980). AHP is a method of measurement based on mathematical and psychological foundations (Kangas 1993). It is an appropriate approach for complex situations that involve the comparison of difficultly quantified decision criteria (Moghadam et al. 2011). Its ability of converting qualitative factors into numerical values provides a quantitative measure of relative priority of each factor in the assessment. Therefore, the weaknesses in the measurement and evaluation steps of the SWOT analysis can be, to some extent, addressed. The combination of AHP in SWOT framework makes it possible to systematically evaluate factors and measure their intensities. Besides, additional values achieved by performing pairwise comparisons between SWOT factors offer a sound basis to examine the present or anticipated situation more comprehensively (Mikko et al. 2000). In this way, AHPSWOT analysis becomes more practical and effective than the stand-alone SWOT or AHP (Tahernejad et al. 2013). Compared to other widely used evaluation tools in decision-making process, like the cost-benefit analysis (CBA), SWOT analysis is more straightforward and easier to be implemented without the need to quantify non-economic and non-quantitative variables (Weber 2014). More importantly, this hybrid method is more suitable for the current situation in China due to the lack of statistical data. Hence, it is of great value to apply AHP in SWOT analysis and this joint method has been used in various fields such as silvopasture adoption, biodiversity conservation, forest management planning, etc. (Shresthaa et al. 2004; Masozera et al. 2006; Arslan and Turan 2009; Zhang and Feng 2013; Guo and Wen 2014). 


\subsection{Research steps}

An approach based on the integration of AHP and SWOT analysis is used to firstly define internal and external influence factors in a hierarchical structure, then evaluate factors in pairs and quantify the relative importance of each factor, followed by calculating the global weighs. Finally, a SWOT strategic quadrilateral (Wang and Gan 1995) is mapped based on the evaluation values of SWOT factors and the development potential can be revealed. The outline for development assessment by applying AHP-SWOT analysis is proposed as the following steps.

Step 1 Identification and quantification of key factors. SWOT analysis on research target is conducted from four aspects, namely, strengths, weaknesses, opportunities, and threats, in order to identify key factors in each aspect (known as SWOT group). Each key factor will be assigned with a score under a simple evaluation standard. The scores here denote key factors' influence on the research goal. Specifically, there are 9 degrees of influence, which are $-4,-3,-2,-1,0,1,2,3$, and 4 (the higher absolute value of score, the greater it influences the target.). In this evaluation standard, the scores of key factors within strength and opportunity are indicated by positive values while weakness and threat factors are with negative values. The identification of key factors, and their scores, was conducted by an expert team (see section 4.1) and the final results will be presented in a table.

Step 2 Establishment of structural model. With the fundamental theory of the AHP, a hierarchical structural model can be developed with the goal at the top of the hierarchy (level A), criteria (specifically $\mathrm{S}, \mathrm{W}, \mathrm{O}$, and $\mathrm{T}$ in this research) at a lower level of the hierarchy (level B), and key factors at the bottom (level C) (Jiang et al. 2012), as shown in Fig. 4. Using this structure, all factors can be measured by the AHP technique (Yuksel and Dagdeviren 2007).

Step 3 Pairwise comparison. Pairwise comparisons between each factor within every SWOT group are carried out for their relative importance. To conduct a pairwise comparison among elements, this paper introduces a simplified evaluation scale from 1 to 5, which is developed from Saaty's fundamental scale (Saaty 1977), as shown in Table 2.

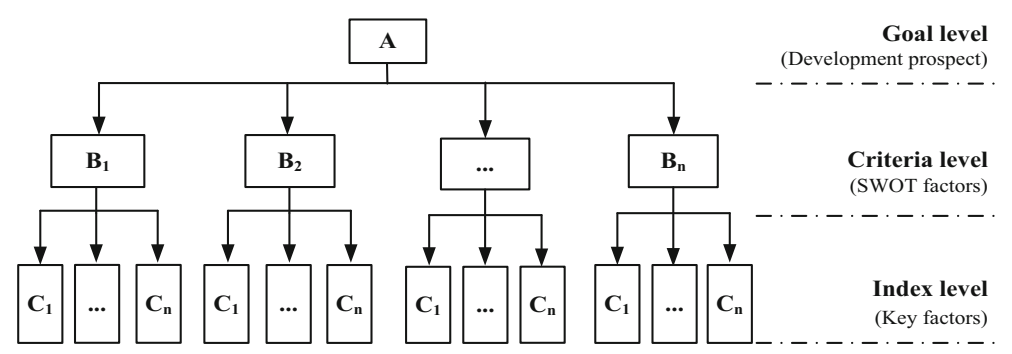

Fig. 4 The hierarchical structure model related to SWOT analysis 
Using the evaluation scale above, the judgment information from expert survey can be collected and a comparison matrix A can be established as Eq. 3.1.

$$
A=a_{i j}=\left[\begin{array}{cccc}
1 & a_{12} & \cdots & a_{1 n} \\
1 / a_{12} & 1 & \cdots & a_{2 n} \\
\vdots & \vdots & \ddots & \vdots \\
1 / a_{1 n} & 1 / a_{2 n} & \cdots & 1
\end{array}\right]
$$

where, $a_{i j}$ is the relative importance of $a_{i}$ and $a_{j}$ and $n$ is the number of factors in each pairwise comparison group.

Step 4 Calculation of relative weights of all factors. In this step, the priorities of SWOT factors and the relative weights of key factors are determined. Weighting vector of a specific element $k$ can be calculated through Eq. 3.2:

$$
w_{k}=\frac{1}{n} \sum_{j=1}^{n} \frac{a_{k j}}{\sum_{i=1}^{n} a_{i j}}(k=1,2, \ldots ., n)
$$

where, $a_{i j}$ is the entry of row $i$ and column $j$ in a comparison matrix of order $n$ and $w_{k}$ is the weighting vector of a specific element $k$ in the pairwise comparison matrix.

When numerous pairwise comparisons are evaluated, their consistency has to be verified so as to ensure that the judgments are consistent along all the answers. AHP provides a measure of the consistency for pairwise comparisons by introducing a consistency ratio (Anderson et al. 2003). The comparisons will be considered reasonable only if the consistency ratio is equal to or less than 0.10 . An approximation of the ratio can be obtained using the Eq. 3.3:

$$
\mathrm{CR}=\frac{\mathrm{CI}}{\mathrm{RI}}
$$

where, $\mathrm{CR}$ is the consistency ratio and $\mathrm{RI}$ is the random index for the matrix size. The value of RI is given in Table 3 (Anderson et al. 2003).

Table 2 Description of evaluation scale (Wan et al. 2013)

\begin{tabular}{ll}
\hline Scale of importance & Meaning \\
\hline 1 & Two factors are equally important \\
3 & The former one is more important, fairly \\
5 & The former one is more important, strongly \\
2,4 & Intermediate values between adjacent scale values \\
Reciprocal & If the latter factor is more important, it will be a reciprocal, that is $a_{j i}=1 / a_{i j}$ \\
\hline
\end{tabular}


Table 3 Average random index (RI) values

\begin{tabular}{lllllllllll}
\hline Matrix size $(n)$ & 1 & 2 & 3 & 4 & 5 & 6 & 7 & 8 & 9 & 10 \\
\hline RI & 0 & 0 & 0.58 & 0.90 & 1.12 & 1.24 & 1.32 & 1.41 & 1.45 & 1.49 \\
\hline
\end{tabular}

where CI is the consistency index that can be obtained from Eq. 3.4.

$$
\mathrm{CI}=\frac{\lambda_{\max }-n}{n-1}
$$

where, $\lambda_{\max }$ is the maximum eigenvalue of comparison matrix A.

Step 5 Calculation of the evaluation values of SWOT factors. Before calculating the evaluation values of SWOT factors, the relative importance of key factors to the goal should be calculated using Eq. 3.5:

$$
W_{\text {key factor }(\text { global })}=W_{\text {SWOT factor }} \times W_{\text {key factor (local) }}
$$

where, $W_{\text {key factor (global) }}$ is the global importance degree of key factors in the hierarchical structural model, $W_{\text {SWOT factor }}$ is the relevant importance degree of SWOT factor in level B, and $W_{\text {key factor (local) }}$ is the local importance degree of each key factor in level $\mathrm{C}$.

After the calculation of global importance degree of each key factor, evaluation values of SWOT factors can be calculated using equation 3.6:

$$
E_{i}=\sum_{j=1}^{N} C_{j} \times W_{j} \quad(i=\mathrm{S}, \mathrm{W}, \mathrm{O}, \mathrm{T})
$$

where, $E_{i}$ is the evaluation value of each SWOT factor, $C_{j}$ is the score of each key factor, $W_{j}$ is the global importance degree of each key factor, $N$ is the number of key factors in each SWOT group.

Step 6 Prospect analysis based on SWOT quadrilateral. In this step, a coordinate system is constituted by four semi-axis in terms of strengths, weaknesses, opportunities, and threats. By doing so, the SWOT quadrilateral can be mapped with the final evaluation values of SWOT factors obtained in step 5. Finally, the development prospect of the research object can be concluded through the priorities of different triangle area in each quadrant.

\section{Prospect analysis of LNG-fueled ships in China}

Referring to the approach of applying AHP in SWOT analysis, this section demonstrates how the proposed methodology is applied to improve the traditional SWOT analysis by conducting a quantitative measure, which figures out the development perspective of LNG-fueled ships in Chinese shipping industry. 


\subsection{Identification of key factors (step 1)}

On the basis of current situation of LNG-fueled ships in China presented in section 2, the key factors and their scores (Table 4) in this study are identified from the current research results (Wang 2011a, b; Xia 2013; Zhou et al. 2013), official documents (Ministry of Transport of China and Water Transport 2013), and in-depth interviews on an expert team. The expert team consisted of three domain experts from the CCS, China MSA and a maritime university, respectively. Since the knowledge and experience of all three experts involved are considered as equivalent, the relative weight of every expert is assigned equally to merge their judgments.

\subsection{Establishment of the structural model (step 2)}

According to the key factors in Table 4, a hierarchical structure can be established, which is shown in Fig. 5.

\subsection{Pairwise comparison (step 3)}

The judgments are obtained from a questionnaire survey distributed to the domain experts who worked in the administrative, industrial, or academic aspects from shipping companies, maritime universities, CCS, local MSAs, oil companies, and other organizations in the field. To obtain a complete overview of the development status and tendency, individuals who have explicit and recognizable role in relevant domains are chosen as experts in this survey. These experts have rich

Table 4 Key factors and corresponding scores

\begin{tabular}{llll}
\hline Groups & & Key factors & Score \\
\hline Strengths & S1 & Reduction of pollutant emission & 3.3 \\
& S2 & Economical operation cost & 3.7 \\
& S3 & Adaptability to major vessel engine & 2.3 \\
Weaknesses & S4 & Abundant reserves worldwide & 2.0 \\
& W1 & High cost of ship conversion & -3.0 \\
& W2 & Non-renewable resources & -1.7 \\
Opportunities & W3 & Increase in volume of fuel tank & -3.0 \\
& W4 & Inconvenience in refueling & -2.3 \\
O1 & Government supporting policy & 4.0 \\
& O2 & Strict emission restriction & 4.0 \\
& O3 & National strategy of optimizing energy structure & 3.7 \\
& O4 & Support from state-level research projects & 3.0 \\
& T1 & Poor infrastructure for LNG-fueled ships & -3.3 \\
\hline
\end{tabular}




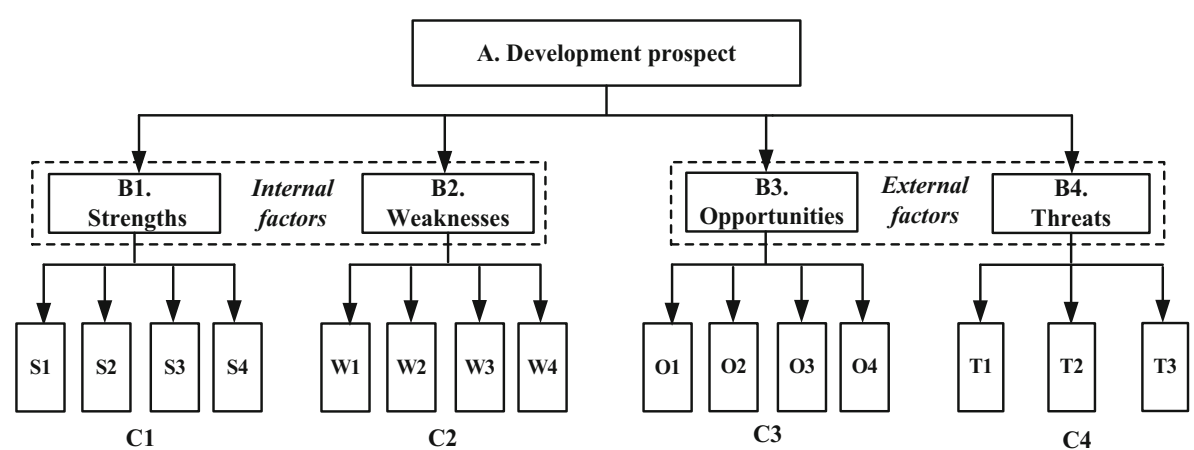

Fig. 5 Hierarchical structure model for SWOT

working experience and possess senior positions in their respective organizations and are familiar with the development progress of LNG-fueled ships in China with regard to various aspects of this research, like LNG trail ships, infrastructures, and relevant policies. Among the 30 questionnaires being distributed, 16 relevant responses have been received. Despite the fact that only a part of questionnaires were collected due to the lack of time, valid data from these sophisticated experts cover a variety of domains that affect the development of LNG-fueled ship in China, the results gained from questionnaires, therefore, still provide relatively comprehensive information for the investigation and analysis on the research. Hence, information from the obtained questionnaires is considered to be valid and utilized in

Table 5 Information of experts

\begin{tabular}{llll}
\hline No. & Duty/research areas & Position/title & Year of working \\
\hline 1 & Waterway transportation & Associate Professor & 9 \\
2 & LNG carrier design & Professor & 9 \\
3 & Marine dual-fuel engine & Professor & 8 \\
4 & New energy-powered ships & Professor & 8 \\
5 & Inspection and certification of ships & Senior surveyor & 9 \\
6 & Marine pollution prevention & Senior surveyor & 8 \\
7 & Formulating rules and regulations for ships & Senior officer & 9 \\
8 & Natural gas technology & Senior officer & 9 \\
9 & Design and construction of ships & Chief engineer & 9 \\
10 & LNG transportation & Faculty head & 9 \\
11 & International trade on fossil fuel & Manager & 10 \\
12 & Working on LNG carrier & Captain & 10 \\
13 & Working on LNG carrier & Chief Officer & 9 \\
14 & Safety supervision on waterway transport & Senior officer & 12 \\
15 & Ship design management & Senior officer & 11 \\
16 & Management of seafarers & Director & 12 \\
\hline & & & 9 \\
\hline
\end{tabular}


this study. Referring to the similar seniority of all experts shown in Table 5, the relative weight of every expert is assigned equally to merge their judgments. Specific information of these experts can be found in Table 5.

The merged judgments are weighted averages from valid questionnaires and each questionnaire is considered of equal importance. Taking level B (criteria level) as a demonstration, the following comparison matrix for this level can then be formed via Eq. 3.1.

\begin{tabular}{l|cccc}
\multicolumn{1}{l}{$\begin{array}{c}\text { Strengths } \\
\text { Strengths }\end{array}$} & Weaknesses & Opportunities & Threats \\
Weaknesses & 1.000 & 1.625 & 1.250 & 1.250 \\
Opportunities & & 1.000 & 0.750 & 0.875 \\
Threats & & & 1.000 & 1.375 \\
& & & & 1.000
\end{tabular}

Comparison matrixes for key factors in level C within strengths, weaknesses, opportunities, and threats groups can be generated in similar process.

\subsection{Calculation of the relative weights of factors (step 4)}

Through Eq. 3.2, normalized weight of each factor in level B can be calculated, which can be shown as the matrix below.

$$
W_{\text {SWOT factors }}=\left[\begin{array}{l}
S \\
W \\
O \\
T
\end{array}\right]=\left[\begin{array}{l}
0.311 \\
0.196 \\
0.271 \\
0.222
\end{array}\right]
$$

Equations 3.3 and 3.4 are used to validate the consistency of pairwise comparison in each level. The result in level $\mathrm{B}$ is as follows:

$$
\mathrm{CR}=\frac{\mathrm{CI}}{\mathrm{RI}}=\frac{\frac{4.0089-4}{4-1}}{0.90}=0.003<0.1
$$

According to this pairwise comparison result, the consistency of the experts' judgments is acceptable. Similar process can then be implemented to lower levels so that the weighting vectors of all pairwise comparison matrixes can be obtained, to represent the local importance degree of each factor.

\subsection{Calculation of the values of SWOT factors (step 5)}

Based on the local importance degree in step 4, the global priorities of the SWOT key factors in level $\mathrm{C}$ are calculated using Eq. 3.5, and the final evaluation value of SWOT factors are obtained through Eq. 3.6; the result is shown as Table 6. 
Table 6 Global weights of key factors and the evaluation value of SWOT factors

\begin{tabular}{|c|c|c|c|c|c|}
\hline SWOT factors & Weights & Key factors & Local weights & Global weights & Evaluation value \\
\hline \multirow[t]{4}{*}{$\mathrm{S}$} & \multirow[t]{4}{*}{0.311} & $\mathrm{~S} 1$ & 0.461 & 0.121 & \multirow[t]{4}{*}{0.923} \\
\hline & & $\mathrm{S} 2$ & 0.230 & 0.072 & \\
\hline & & S3 & 0.234 & 0.073 & \\
\hline & & $\mathrm{S} 4$ & 0.147 & $0.046^{\mathrm{a}}$ & \\
\hline \multirow[t]{4}{*}{ W } & \multirow[t]{4}{*}{0.196} & W1 & 0.359 & 0.070 & \multirow[t]{4}{*}{-0.500} \\
\hline & & W2 & 0.166 & 0.033 & \\
\hline & & W3 & 0.235 & $0.046^{\mathrm{b}}$ & \\
\hline & & W4 & 0.240 & 0.047 & \\
\hline \multirow[t]{4}{*}{$\mathrm{O}$} & \multirow[t]{4}{*}{0.271} & $\mathrm{O} 1$ & 0.348 & 0.094 & \multirow[t]{4}{*}{1.016} \\
\hline & & $\mathrm{O} 2$ & 0.230 & 0.062 & \\
\hline & & $\mathrm{O} 3$ & 0.243 & 0.066 & \\
\hline & & $\mathrm{O} 4$ & 0.179 & 0.048 & \\
\hline \multirow[t]{3}{*}{$\mathrm{T}$} & \multirow[t]{3}{*}{0.222} & $\mathrm{~T} 1$ & 0.514 & 0.114 & \multirow[t]{3}{*}{-0.626} \\
\hline & & $\mathrm{T} 2$ & 0.294 & 0.065 & \\
\hline & & T3 & 0.192 & 0.043 & \\
\hline
\end{tabular}

${ }^{\mathrm{a}} 0.04556$

${ }^{\mathrm{b}} 0.04604$

4.6 Prospect analysis based on SWOT quadrilateral (step 6)

A four-quadrant coordinate system is used for the four variables, the evaluation value of S, W, O, and T. (Wang and Gan 1995; Jiang et al. 2012). The evaluation value of each factor is plotted on the corresponding semi-axis of the coordinate system, and the SWOT quadrilateral is made by connecting the four points, namely, (Es, 0), (0, Eo), $(\mathrm{Ew}, 0)$, and $\left(0, \mathrm{E}_{\mathrm{T}}\right)$ in sequence, which is shown as Fig. 6.

Finally, the areas of the four triangles in each quadrant are calculated to represent the development prospect of LNG-fueled ships in Chinese shipping industry. The area of each triangle is $S_{\mathrm{SAO}}=0.468884, S_{\mathrm{WAO}}=0.254, S_{\mathrm{WAT}}=0.1565$, and $S_{\mathrm{SAT}}=0.288899$, respectively, which can be therefore clearly ranked as $S_{\mathrm{SAO}}>S_{\mathrm{SAT}}>S_{\mathrm{WAO}}>S_{\mathrm{WAT}}$.

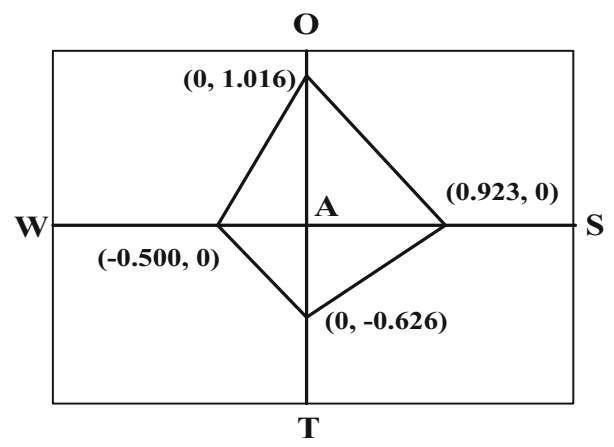

Fig. 6 SWOT quadrilateral of LNG-fueled ships development prospect 


\subsection{Discussion}

It can be seen from the SWOT quadrilateral that externally the "opportunity" (1.016) of the development prospect of LNG-fueled ships in China is greater than "threat" $(0.626)$, and internally "strength" $(0.923)$ is much greater than "weakness" $(0.500)$ as well. This results in the largest area of $S_{\mathrm{SAO}}$. Being facilitated by both inner strengths and external opportunities, the great opportunity and obvious strength to develop LNG-fueled ships in China is indicated by the analysis. This reveals that the development prospect of LNG-fueled ships in China belongs to a growth-oriented type, with a trend of continuous growth in the future.

According to the 12th Five-Year Plan (published in 2010 by the Chinese Government) and a guidance document (Ministry of Transport of China and Water Transport 2013) for the development of LNG as marine fuel published by China's Ministry of Transport on November 4, 2013, a series of actions will be taken (the authority is taking action to incentivize and ease the cost burden during the transition to LNG as a marine fuel by setting special funds for energy conservation and $\mathrm{CO}_{2}$ emissions reduction in the transportation industry, exempting the tax for ships and vehicles which use clean energy, carrying out research on layout of wharves for the berthing of LNG-fueled ships and providing certain support for standardized ships using clean energy, to name a few) to further facilitate the application of LNG in waterway transportation so as to alleviate the emission of exhaust and optimize the energy usage, specifically, to significantly increase the share of LNG in total inland cargo ships' energy consumption to $10 \%$ by 2020 (Chen 2013). Hence, the results obtained in this study meet with the Chinese current situation for LNG-fueled ships, highlighting the main advantages of using LNG as marine fuel, that is, (1) reducing pollutant emission, (2) saving operation cost, (3) good adaptability to major vessel engines, and (4) abundant reserves. Moreover, the application of LNG as a marine fuel in China has been supported by a series of governmental promotions and state-level research projects.

There are six key factors that influence the development of LNG-fueled ships most according to their comparatively high overall weights (all together more than $50 \%$ ); they are "reduction of pollutant emission" (S1, 0.121), "poor infrastructure for LNGfueled ships" (T1, 0.114), "government supporting policy" (O1, 0.094), "adaptability to major vessel engine" (S3, 0.073), "economical operation cost" (S2, 0.072), and "high cost of ship conversion" (W1, 0.070), respectively. This indicates that some existing weaknesses and threats are still important development-hampering factors on the application of LNG in Chinese shipping industry. To mitigate the most important factors in "threats" (T1) and "weaknesses" (W1), respectively, improvement actions are needed for the reconstruction technologies of LNG-fueled ships and the strengthening of infrastructure to better support LNG-fueled ships operation, especially the infrastructure improvement on aquatic LNG-fueling stations, LNG storage stations (along the inland waterways), and wharf boats for LNG refueling.

\section{Conclusion}

By using the AHP-SWOT method, this paper investigates the potential of LNG-fueled ships in China with respect to its strengths and weakness, as well as opportunities and 
threats. A growth-oriented trend of the use of LNG in Chinese shipping industry is shown, which reveals that the application of LNG onboard ships, as a green energy in marine industry, has a bright prospect in China. However, the threats and weaknesses identified in this paper should not be overlooked; otherwise, the development speed and efficiency will be hindered. For strategic development, it is recommended that stakeholders should not only focus on the opportunities and its advantages of LNGfueled ships in China but also mitigate the threats and overcome weaknesses for the industrialization of LNG-fueled ships in China.

The results obtained from the analysis in this paper should provide very useful information for stakeholders and policy makers of the Chinese shipping industry. Meanwhile, given the increasing complexity of shipping situations which involve multiple influencing factors, the method utilized in this study can be further applied either to develop new strategies, or as a stand-alone technique to prioritize existing strategies through pairwise comparison. In practice, this work provide a reference of identification of factors with the highest importance degree, which in turn helps to improve the investment allocation and achieve the goal of steady and efficient development of this new maritime energy in Chinese shipping industry. Moreover, the evaluation results, to some extent, are in accordance with the current situation in China, which shows a fair reasonableness of using this hybrid method in the prospect analysis of LNG-fueled ships in China. It is worth noting that the current method and research findings can be further optimized and improved when more data or judgments from experts are obtained and incorporated, so as to conduct a more comprehensive analysis. With this work's foundation, similar processes can be conducted in the prospect analysis of using LNG as a marine fuel in other countries as well.

Acknowledgments This work is supported by the National Science Foundation of China (NSFC) under Grant No. 51209165, the EU FP7 Marie Curie IRSES project "ENRICH" (No. 612546), the Fundamental Research Funds for the Central Universities (WUT: 2013-IV-121), the Innovation Groups Project of Hubei Province Natural Science Foundation (No. 2013CFA007), and the University of Manitoba's University Research Grant Program (URGP) (No. 42227). In addition, the authors would like to thank the reviewers for the great effort made in the precise reading and their valuable comments to this work.

\section{References}

Acciaro M (2014) Real option analysis for environmental compliance: LNG and emission control areas. Transp Res D-Tr E 28:19-27

Anderson DR, Sweeney DJ, Williams TA (2003) An introduction to management science: quantitative approaches to decision making, 10th edn. South-Western, Div of Thomson Learning, California

Arslan O, Turan O (2009) Analytical investigation of marine casualties at the Strait of Istanbul with SWOTAHP method. Marit Policy Manag 36(2):131-145

Burel F, Taccani R, Zuliani N (2013) Improving sustainability of maritime transport through utilization of liquefied natural gas (LNG) for propulsion. Energy 57:412-420

Chen YQ (2013) Current development trend of ship technologies. Academic Report: 1218-2013. Wuhan University of Technology, Wuhan

Cheng TCE, Lai K, Lun VYH, Wong CWY (2013) Green shipping management. Transp Res E-Log 55:1-2

China Classification Society (2012) Rules for green ships, ministry of transport of the People's Republic of China, Beijing

CNII (2014) Trend of average import price of LNG in China from 2006-2013. http://www.chyxx.com/ industry/201305/202303.html. Accessed December 82014 
Dong QY (2011) Simulation research on a fuel supply system of LNG engine. Master Dissertation. Jilin University, P. R. China

Gao HJ (2014) 2014 International LNG Technology Summit. http://lng.zhenweievents.com/cn/. Accessed August 132014

Guo XZ, Wen XX (2014) Fuzzy comprehensive evaluation of the bus service level based on AHP. J Transp Inf and Saf 32(3):42-46 (in Chinese)

Halla F (2007) A SWOT analysis of strategic urban development planning: the case of Dar es Salaam City in Tanzania. Habitat Int 31(1):130-142

Heir H, Bjornsen J, Hosoien A, Eide TL (2011) Infrastructural challenges for LNG fueled vessels in the SECA. Unpublished report of course TPG4140 Natural Gas, Distribution. Norwegian University of Science and Technology, Norway

Hill T, Westbrook R (1997) SWOT analysis: it's time for a product recall. Long Range Plan 30(1):46-52

Hu Q (2013) A demand growth for LNG fueled ships. China Industry News, July 222013

ICS (2013a) Shipping and world trade. International Chamber of Shipping. http://www.ics-shipping.org/ shipping-facts/shipping-and-world-trade. Accessed December 302013

ICS (2013b) Shipping, world trade and the reduction of $\mathrm{CO}_{2}$ emissions. International Chamber of Shipping. http://www.ics-shipping.org/docs/default-source/resources/environmental-protection/shipping-worldtrade-and-the-reduction-of-co2-emissions.pdf?sfvrsn=10. Accessed December 302013

IMO (2009) Second IMO GHG study 2009. Update of the 2000 IMO GHG study, final report covering phase 1 and phase 2, MEPC 59/INF.10

Jiang QZ, Xu YM, Xin WJ, Song ZZ, Song QQ, Ke M (2012) SWOT-AHP hybrid model for vehicle lubricants from CNPCLC. China Petrol Sci 9(4):558-564

Kajanus M, Kangas J, Kurttila M (2004) The use of value focused thinking and the A'WOT hybrid method in tourism management. Tourism Manage 25:499-506

Kangas JA (1993) Multi-attribute preference model for evaluating the reforestation chain alternatives of a forest stand. For Ecol Manag 59:271-288

Kumar S, Kwon HT, Choi KH, Lim W, Cho JH, Tak K, Moon I (2011) LNG: An eco-friendly cryogenic fuel for sustainable development. Appl Energ 88(12):4264-4273

Kurttila M, Pesonen M, Kangas J, Kajanus M (2000) Utilizing the analytic hierarchy process AHP in SWOT analysis - a hybrid method and its application to a forest-certification case. Forest Policy Econ 1(1):41-52

Lin WS, Zhang N, Gu AZ (2010) LNG (liquefied natural gas): a necessary part in China's future energy infrastructure. Energy 35(11):4383-4391

Luo YH, Jin WZ (2014) The effect of Xiamen-Shenzhen railway on Shanwei's road transportation and the development strategy. J Transp Inf and Saf 32(4):113-118 (in Chinese)

Ma LW, Geng J, Li WQ, Liu P, Li Z (2013) The development of natural gas as an automotive fuel in China. Energ Policy 62:531-539

Masozera MK, Alavalapati JRR, Jacobson SK, Shresta RK (2006) Assessing the suitability of communitybased management for the Nyungwe Forest Reserve, Rwanda. For Policy Econ 8(2):206-216

Mikko K, Mauno P, Jyrki K, Miika K (2000) Utilizing the analytic hierarchy process AHP in SWOT analysis - a hybrid method and its application to a forest-certification case. For Policy Econ 1:41-52

Ministry of Transport of China, General Office (2014) The pilot demonstration project of application of LNG in waterway transportation. http://www.gov.cn/xinwen/2014-10/23/content_2769326.htm. Accessed 23 Dec 2014

Ministry of Transport of China, Water Transport Bureau (2013) Guidance on the application of LNG in waterway transportation. http://www.moc.gov.cn/zfxxgk/bnssj/syj/201311/t20131104_1507474.html. Accessed 4 Nov 2013

Moghadam MK, Jahromi ARM, Nooramin AS (2011) A fuzzy AHP decision support system for selecting yard cranes in marine container terminals. WMU J Marit Aff 10(2):227-240

Nikopoulou Z, Cullinane K, Jensen A (2013) The role of a cap-and-trade market in reducing $\mathrm{NO}_{x}$ and $\mathrm{SO}_{x}$ emissions: prospects and benefits for ships within the Northern European ECA. Proc IMechE M. J Eng Marit Environ 227(2):136-154

Qianzhan (2014) China, on its way to the biggest LNG import country. http://www.qianzhan.com/analyst/ detail/220/141120-0f1c781a.html Accessed December 82014

Saaty TL (1977) A scaling method for priorities in hierarchical structure. J Math Psychol 15(3):234-281

Saaty TL (1980) Analytic hierarchy process. McGraw-Hill International, New York

Shi GH, Jing YY, Wang SL (2010) Development status of liquefied natural gas industry in China. Energ Policy 38(11):7457-7465

Shresthaa RK, Alavalapati RR, Kalmbacher RS (2004) Exploring the potential for silvopasture adoption in south-central Florida: an application of SWOT-AHP method. Agric Syst 81(3):185-199 
Tahernejad MM, Khalokakaie R, Ataei M (2013) Determining proper strategies for Iran's dimensional stone mines: a SWOT-AHP analysis. Arab J Geosci 6(1):129-139

Wan CP, Yan XP, Zhang D, Fu SS (2013) Reliability analysis of a marine LNG-diesel dual fuel engine. Chem Eng Trans 33:811-816

Wang L (2011a) China’s entering “Wreck Removal Convention” strategy research based on SWOT. Master's Dissertation. Wuhan University of Technology. Wuhan, P. R. China

Wang SR (2011b) Analysis on current situation of diesel-LNG dual fueled ships in inland waterways of China. China Waterw Transp 11(7):4-7, in Chinese

Wang BG, Gan JS (1995) An analytical SWOT model of marketing strategies. Syst Eng Theor Pract 12:34-40

Weber J (2014) The process of crafting bicycle and pedestrian policy: a discussion of cost-benefit analysis and the multiple streams framework. Transp Policy 32:132-138

Xia ZY (2013) Analysis on application of diesel-LNG dual fueled ships in inland waterways of China. China Waterw Transp 6:39-42 (in Chinese)

Yuksel I, Dagdeviren M (2007) Using the analytic network process (ANP) in a SWOT analysis — a case study for a textile firm. Inform Sci 177(16):3364-3382

Zhang YC, Feng L (2013) Development assessment of leisure agriculture in Henan province of China based on SWOT-AHP method. J Ind Eng Manag 6(2):642-653

Zhou SH, Shen X, Liu XJ, Li G, Yang Y (2013) Prospect of LNG application to inland water transportation in China. Nat Gas Ind 33(2):81-89 (in Chinese) 